\title{
Aplikasi Penilaian Improvement Activity (Kaizen) Menggunakan Metode Point System pada PT. Honeywell Indonesia
}

\author{
Niel Hilwert Simbolon ${ }^{1}$, Ilivia², Ricak Agus Setiawan ${ }^{3}$ \\ ${ }^{1}$ Jurusan Sistem Informasi STT Indonesia Tanjungpinang \\ Jln. Pompa Air No. 28 Tanjungpinang Kepulauan Riau Indonesia \\ 1niel.hilwertsimbolon@gmail.com \\ ${ }^{2}$ Iliviaphang@gmail.com \\ ${ }^{3}$ ricak.agus@gmail.com
}

\begin{abstract}
Intisari-Manajemen penilaian terhadap evaluasi kinerja pada perusahaan yang dilakukan secara tidak terstruktur dan dengan proses manual akan menyebabkan sistem pengambilan keputusan oleh pimpinan tidak akurat. Hal ini tentu akan sangat merugikan perusahaan asing terutama pada Honeywell Aerospace yang merupakan perusahaan bergerak dibidang elektronik navigasi pesawat terbang. Penelitian ini bertujuan untuk menganalisa semua faktor-faktor penghambat pada proses evaluasi kinerja terhadap aktivitas Kaizen (improvement activity) yang akan dipecahkan dengan suatu sistem integrasi dengan metode point system untuk menyederhanakan proses penilaian kerja secara manual menjadi proses satu pintu secara otomatis. Pada sistem yang sedang berjalan, perusahaan Honeywell pada departemen HOS (Honeywell Operating System) masih menggunakan sistem manual yang harus mencatat setiap data hasil kinerja suatu aktivitas Kaizen dan menyerahkan formulir opportunity sheet untuk proses penilaian. Yang kemudian hasil penilaian masih akan di proses secara ulang di input ke dalam Microsoft Excel. Dengan metode point system dapat mengakomodir kebutuhan, karena sistem ini mampu memberikan value/nilai pada setiap kegiatan/pekerjaan dalam organisasi dengan lebih obyektif, sesuai dengan beban setiap pekerjaan masing-masing, sehingga mengurangi perdebatan dalam penyusunan kebijakan tentang compensation. Hasil dari penelitian ini dimaksudkan untuk membangun suatu program aplikasi yang paling diminati dan popular untuk mempercepat terlaksananya suatu proses penilaian aktivitas Kaizen. Program aplikasi dibangun terintegrasi dengan metode point system yang terstruktur dan juga proses Auto Email yang secara otomatis mengirim notifikasi kepada manager setelah proses inputan selesai. Hasil akhir dari penelitian adalah berupa suatu program aplikasi sebagai Sistem Pendukung Keputusan yang dapat mengolah proses penilaian dan menyajikan data laporan secara instan dengan hanya klik pada form menu satu untuk semua (one for all).

Kata Kunci : Sistem Pendukung Keputusan, Point System, Kaizen, Evaluasi Kinerja, Auto Email, Improvement Activity.
\end{abstract}

Abstract-Management of the assessment of the performance evaluation in the company which is carried out is not structured and manual processes will cause the decision-making system by the leadership to be inaccurate. This of course will be very detrimental to the company, especially Honeywell Aerospace, which is a company engaged in aircraft navigation electronics. This study aims to analyze all the inhibiting factors in the performance evaluation process of Kaizen activities (improvement activities) which will solve system integration problems using the point method to simplify the process process manually. In the running system, the Honeywell company in the HOS (Honeywell Operating System) department still uses a system manual which must record every data on the performance results of a Kaizen activity and submit an opportunity sheet for the delivery process. Production results will still be reprocessed into Microsoft Excel. With the point system method can accommodate needs, because this system is able to provide value/value to every activity/job in the organization more objectively, according to the load of each individual job, thereby reducing the policy on compensation. The results of research conducted to build a program that is most popular and popular to accelerate the production process of Kaizen activities. The application program is built integrated with a structured point system method and also an Auto Email process that automatically sends notifications to managers after the input process is complete. The final result of the research is in the form of an application program as a Decision Support System that can process the production process and present reports instantly by simply clicking on the one for all (one for all) menu form. Keywords: Decision Support System, Point System, Kaizen, Performance Evaluation, Auto Email, Improvement Activity.

\section{Pendahuluan}

Salah satu perusahaan swasta asing yang saat ini sedang beroperasi di kawasan Lobam, Bintan adalah PT. Honeywell Indonesia yakni perusahaan teknologi di bidang Aerospace dan manufaktur anak usaha Honeywell International asal Amerika Serikat yang masuk ke Bintan sejak tahun 2005. Fasilitas manufaktur Honeywell Aerospace di Lobam memproduksi avionik dan sistem komunikasi pesawat, termasuk kotak hitam (recorder), untuk pesawat dan helikopter dan juga sistem navigasi pesawat terbang (EGPWS) dan traffic collision alerting system (TCAS).

Selain di butuhkannya sumber daya manusia yang handal dalam mengelola proses produksi tersebut, kemajuan teknologi juga berperan dalam meningkatkan kemajuan proses tersebut. Sampai saat ini masih ada beberapa proses tertentu di bidang proses improvement activity yang masih menggunakan cara manual. 
Permasalahan yang terjadi pada proses improvement activity di departemen Honeywell Operating System (HOS) dimana proses masih menggunakan sistem manual yakni setiap karyawan diharuskan untuk mencatat setiap kegiatan improvement dalam sebuah formulir yang dinamakan Opportunity Sheet.

Pada proses ini terjadi beberapa masalah dimana karyawan yang sudah memberikan formulir Opportunity Sheet dan sheet tersebut tidak dapat ditemukan ataupun hilang sehingga karyawan diharuskan untuk mengisi formulir baru, beberapa masalah lain dimana terkadang formulir diisi dengan informasi kegiatan yang kurang jelas dan terkadang pimpinan tidak dapat memahami dengan jelas dan ada juga dimana tulisan pada kertas tidak dapat dibaca dengan jelas. Kekurangan lainnya dimana Opportunity Sheet ini tidak dapat mencantumkan gambar suatu kegiatan yang telah dilakukan yang merupakan salah satu unsur penting untuk tingkat poin penilaian sehingga karyawan harus dipersulit untuk memprint gambar kegiatan kemudian dilampirkan pada formulir Opportunity Sheet.

Masalah yang kemudian dihadapi pada proses ini dimana setiap kegiatan improvement yang dilakukan oleh karyawan tidak maksimal dikarenakan karyawan tidak mau direpotkan untuk mencetak gambar dan hanya membuat suatu kegiatan biasa saja yang tidak memberikan improvement yang lebih.

Pada proses berikutnya dimana Opportunity Sheet tersebut akan diolah kembali melalui proses penilaian secara manual dimana pimpinan dan anggota komite harus memeriksa apakah suatu kegiatan improvement yang telah diberikan karyawan tersebut sudah memenuhi syarat untuk tingkat poin yang sudah ditentukan dan proses ini membutuhkan waktu 10 sampai 20 menit per Opportunity Sheet yang sangatlah memakan waktu yang cukup lama yang disebabkan oleh banyaknya data yang masuk sehingga pimpinan/komite dapat menghabiskan waktu hingga satu minggu untuk proses penilaian dan juga sering kali terjadi penilaian yang tidak sesuai akibat pencatatan secara manual karena ditulis pada Opportunity Sheet berupa kertas kerja yang sering mengakibatkan hilangnya data tersebut.

Selain itu proses penyimpanan data-data Opportunity Sheet dan data-data hasil penilaian beserta proses approval saat ini masih merupakan suatu sistem yang tidak tertata dengan baik dimana sering timbul tidak ditemukannya data-data yang dibutuhkan yang berhubungan dengan data laporan hasil penilaian dan nominasi kaizen terbaik oleh setiap karyawan. Pembuatan laporan untuk disampaikan kepada pimpinan terkadang menghasilkan laporan yang salah dalam penyajian dan pembuatannya juga membutuhkan waktu yang lama untuk mengumpulkan semua kertas-kertas kerja (history card).

Berdasarkan latar belakang uraian di atas maka penulis tertarik untuk melakukan penelitian Skripsi pada proses improvement activity (Kaizen) di bagian departemen Honeywell Operating System (HOS) dimana penulis yang juga salah satu karyawan pada perusahaan ini berniat untuk merancang suatu sistem terintegrasi dalam proses improvement activity di PT. Honeywell Indonesia dengan memilih judul "Aplikasi Penilaian Improvement Activity (Kaizen) Menggunakan Metode Point System Pada PT. Honeywell Indonesia".

\section{Metodologi Penelitian}

Kaizen adalah salah satu strategi dalam menerapkan Lean Manufacturing pada sebuah perusahaan. Istilah Kaizen berasal dari bahasa Jepang yaitu kata KAI [改] dan ZEN [善]. Kata "KAI" yang diterjemahkan ke dalam Bahasa Indonesia memiliki arti "berubah" sedangkan "ZEN" yang artinya adalah "baik". Jadi jika diartikan secara langsung maka arti Kaizen adalah "merubah menjadi lebih baik". Di dalam Industri, Kaizen merupakan suatu strategi yang dipergunakan untuk melakukan peningkatan secara terus-menerus ke arah yang lebih baik terhadap proses produksi, kualitas produk, pengurangan biaya operasional, mengurangi pemborosan hingga peningkatan keamanan kerja.

Penerapan strategi Kaizen dalam sebuah perusahaan memerlukan usaha dan kerjasama dari semua level karyawan perusahaan mulai dari level terendah sampai dengan yang Manajemen Puncak. Penerapan Strategi Kaizen lebih difokuskan pada perbaikan-perbaikan yang berskala kecilmenengah sehingga proyek-proyek perbaikan dapat dilakukan dengan cepat dan tepat sasaran. Rata-rata proyek-proyek Kaizen diselesaikan dalam waktu yang singkat seperti dalam hitungan minggu dan tidak memerlukan biaya perbaikan yang besar. Metode-metode yang dipergunakan dalam identifikasi proyek-proyek Kaizen antara lain adalah Metode DMAIC (Design Measure Analyze Improve Control) dan Metode PDCA (Plan Do Check Action).

Tujuan dan Keuntungan setelah menerapkan Aktivitas Strategi Kaizen antara lain :

1. Menghindari biaya yang tersembunyi yang berasal dari 7 pemborosan (seven waste) dalam proses Produksi.

2. Memberikan nilai tambah pada operasional produksi sehingga dapat meningkatkan kualitas produk dengan biaya terendah dan memperpendek waktu pengiriman kepada pelanggan.

3. Dapat melakukan perubahan dalam waktu yang relatif singkat dan biaya yang rendah.

Kaizen bukan hanya mengidentifikasikan proses-proses yang perlu diperbaiki atau ditingkatkan, tetapi juga melakukan evaluasi terhadap prosedur dan standarisasi pekerjaan yang telah ada ataupun menetapkan standar baru dalam pekerjaan.

Berbagai penelitian telah dilakukan hingga saat ini berkaitan dengan evaluasi kinerja maupun metode point system sebagai salah satu metode dalam evaluasi kinerja. McCormick et al. (1972) menggunakan analisis jabatan untuk menghubungkan kebutuhan bakat dalam pekerjaan dengan tingkat gaji yang diberikan. Doverspike et al. (1983) membuktikan keandalan metode point system untuk melakukan evaluasi kinerja. Grams and Schwab (1985), Schwab dan Grams (1985), Doverspike and Barrett (1984), Arvey (1986) and Acker (1987) melakukan studi mengenai kesalahan yang berhubungan dengan gender dalam pelaksanaan evaluasi kinerja. Robinson et al. (1974) membandingkan metode point system dengan empat metode evaluasi jabatan lainnya. Rodgers (1988) menggunakan teknikteknik evaluasi kinerja untuk mengidentifikasi cara yang efektif untuk mengubah persyaratan jabatan. Steinberg (1999) mengusulkan untuk mengakomodasi faktor emosi karyawan dalam pelaksanaan evaluasi jabatan.

Metode Point System sering digunakan oleh perusahaanperusahaan yang relatif maju management-nya karena mengakomodir kebutuhan objektivitas dalam penyusunan 
kebijakan yang terkait dengan compensation atau remuneration policy.

Dikatakan mengakomodir kebutuhan, karena sistem ini mampu memberikan value/nilai pada setiap kegiatan/pekerjaan dalam organisasi dengan lebih obyektif, sesuai dengan beban setiap pekerjaan masing-masing, sehingga mengurangi perdebatan dalam penyusunan kebijakan tentang compensation.

Metode Point System ini berkembang pesat bahkan beberapa lembaga konsultan internasional seperti Hay, Mercer, Bipers, CRG telah mem-patentkan metode yang mereka kembangkan masing-masing dari Point System ini.

Berikut ini akan dijelaskan beberapa langkah dalam mengimplementasikan metode Point System :

1. Membentuk Tim Penilai Kinerja (Komite)

Tim ini dibentuk oleh dewan pimpinan dan melaporkan hasil kerjanya pada dewan pimpinan. Sebaiknya dalam pemilihan anggota tim, jumlahnya dibuat ganjil, agar apabila tidak ada kata sepakat dalam perundingan, maka dapat diputuskan lewat voting. Seluruh anggota tim harus diberikan pemahaman tentang Job Evaluation, termasuk salah satu tugas pokok-nya adalah dalam hal memilih compensable factors.

\section{Pemilihan Compensable Factors}

Langkah kedua ini sangat penting, yaitu memilih dan menyetujui Compensable Factors. Apa itu Compensable Factors (CF's) ? CF's adalah faktor faktor yang nantinya akan mempengaruhi pemberian kompensasi. Mengapa bisa begitu, karena dari faktor faktor yang dipilih tersebut, maka value/nilai setiap kategori kinerja akan didapatkan dan nantinya akan diperbandingkan dengan kinerja karyawan yang lain dalam organisasi.

3. Membuat Definisi dari Setiap Faktor yang di-Pilih

Definisi dari setiap CF's harus dibuat dengan bahasa yang sederhana dan mudah dipahami sehingga meminimalisasi kesalahpahaman dari para anggota tim. Definisi yang sudah dibuat dan disetujui menjadi acuan bagi seluruh anggota tim. Contoh Definisi yaitu :

Persyaratan suatu kegiatan (requirement) : adalah derajat persyaratan dari suatu aktivitas improvement atas pelaksanaan pekerjaan sesuai dengan persyaratannya seperti ada tidaknya kelengkapan penjelasan kegiatan melalui gambar.

4. Menyusun Tingkatan atau Level pada Setiap CF's serta memberikan Definisi dan Point pada Tiap Level

Langkah selanjutnya adalah membuat tingkatan atau level pada setiap faktor sekaligus memberikan definisi serta point atau skor pada setiap levelnya.

Setelah itu, akan diberikan bobot pada masing-masing faktor. Bobot masing-masing faktor akan berbeda berdasarkan derajat kepentingan (degree of significance) dari setiap faktor bagi setiap jabatan dalam organisasi. Total bobot harus-lah $100 \%$.

5. Melaksanakan Analisis Kinerja

Analisis kinerja dilakukan dengan lebih terarah atau fokus karena jelas tujuan serta Compensable Factors apa saja yang sudah dipilih dan disetujui untuk dilakukan analisis.

6. Pelaksanaan Evaluasi Kinerja

Setelah semua informasi diperoleh, yaitu berupa kumpulan kegiatan dari setiap aktivitas serta berbagai informasi tentang kondisi nyata setiap faktor dalam setiap kinerja.
Setelah itu, akan dilakukan evaluasi kinerja oleh semua anggota tim dan diberikan nilai/point/skor pada setiap kinerja.

7. Penyusunan Work Grading dari hasil Penilaian Kinerja. Setelah didapat skor pada setiap kinerja, maka langkah selanjutnya adalah membuat pengelompokan atau grading pada setiap kinerja. Hal yang penting dalam langkah ini adalah menentukan berapa jumlah grade atau kelas, biasanya disebut dengan Work Grade atau Work Class. Penentuannya bisa memakai jumlah grade yang lama atau menyusun/menentukan jumlah grade yang baru. Dalam setiap grade, maka kinerja kinerja yang mempunyai point (range point) yang sama akan mempunyai grade (golongan) yang sama pula.

Berikut adalah Rumus Metode Point System :

Total Point $=\sum_{i=1}^{n} W^{i} * F^{i}$

Dimana :

$$
\begin{aligned}
& \mathrm{W}=\text { Bobot }(\text { weight }) . \\
& \mathrm{F}=\text { Faktor point tingkatan } 0-4 .
\end{aligned}
$$

\section{HASIL DAN PEMBAHASAN}

Dalam penelitian ini yang dijadikan sebagai objek penelitian yaitu perancangan Aplikasi Penilaian Improvement Activity (Kaizen) Menggunakan Metode Point System pada PT. Honeywell Indonesia yang beralamat di J1. Teratai Lot D 16, D27 BIIE Lobam Bintan Kepulauan Riau. Proses Improvement Activity yang dimaksud dalam sistem ini berada pada departemen Honeywell Operating System (HOS).

Rancangan ini meliputi Flowmap yang diusulkan, Flowchart Proses Metode Point System, Diagram Konteks, Data Flow Diagram, Entity Relationship Diagram, Struktur Program, Rancangan Input, Rancangan Proses dan Rancangan Output.

1. Prosedur Submit dan Penilaian Poin Awal (Register Point) Improvement Activity (Kaizen) Usulan pada PT. Honeywell Indonesia

Prosedur usulannya sebagai berikut :

a. Employee yang telah memiliki data Kaizen pada proses sistem usulan tidak perlu lagi mengisi formulir Opportunity Sheet.

b. Diproses ini Employee langsung melakukan input data aktivitas Kaizen ke dalam aplikasi komputer yang telah dirancang sesuai standar dan kemudian data tersimpan dalam suatu database.

c. Data aktivitas Kaizen yang akan diinput oleh employee sudah dapat dilengkapi dengan gambar aktual suatu aktivitas atau juga hanya menginput penjelesan secara terperinci dengan inputan kalimat kedalam aplikasi tersebut.

d. Employee akan memilih terlebih dahulu golongan ataupun tipe kaizen yang akan di submit. Aplikasi sudah dilengkapi keterangan lengkap tentang definisi tipe kaizen untuk mempermudah employee ketika submit data aktivitas.

e. Setiap data aktivitas yang sudah diinput oleh employee ke dalam database akan masuk dalam proses penilaian oleh aplikasi dengan memberikan poin awal sesuai kriteria register point. 
f. Dan jika data aktivitas yang telah di input sudah sesuai standar kriteria Kaizen maka data tersebut akan diproses oleh aplikasi dan kemudian akan secara otomatis aplikasi membuat ringkasan tentang aktivitas tersebut dan mengirimkan email kepada komite sekaligus kepada pimpinan.

g. Ringkasan data aktivitas yang telah dikonversi kedalam suatu email diterima oleh komite untuk selanjutnya dilakukan proses pengolahan.

h. Komite juga akan membuat laporan data aktivitas kaizen berdasarkan hasil proses penilaian yang telah diolah oleh sistem aplikasi setiap bulannya kepada pimpinan untuk di review untuk proses nominasi Kaizen terbaik.

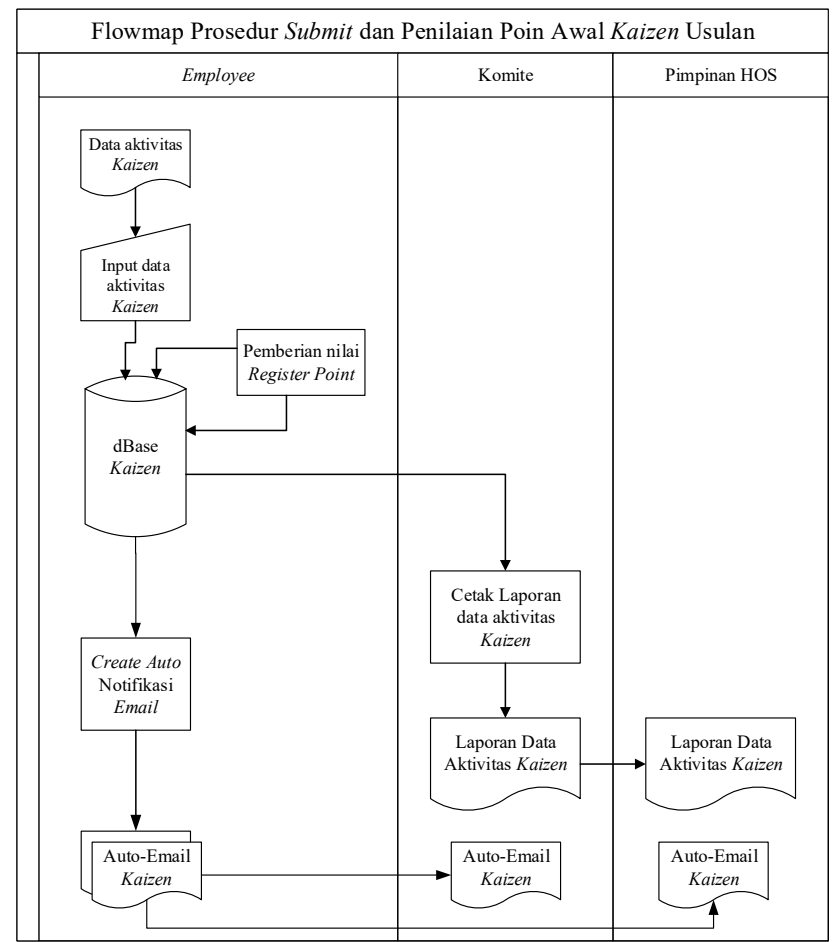

Gambar 1. Flowmap Prosedur Submit dan Penilaian Awal Kaizen Usulan

2. Prosedur Approval Nominasi Kaizen Terbaik (The Best Kaizen) Usulan pada PT. Honeywell Indonesia

Prosedur usulannya sebagai berikut :

a. Dari proses penilaian dengan pemberian poin awal (register point) yang telah dilakukan secara otomatis oleh sistem aplikasi maka selanjutnya akan dilakukan pemberian final point oleh bagian pimpinan HOS secara komputerisasi untuk dapat menghasilkan Kaizen terbaik sehingga dapat dinominasikan kepada direktur perusahaan.

b. Sistem aplikasi sudah dirancang dengan proses formula berdasarkan rumus metode point system untuk tahap kalkulasi final point (poin akhir).

c. Pimpinan HOS melakukan proses pemberian final point dengan langsung input nilai factor point terhadap setiap faktor item pada sistem aplikasi untuk setiap data aktivitas Kaizen yang telah diberi register point oleh sistem aplikasi dan kemudian sistem aplikasi mengkalkulasi secara otomatis final point atau reward point. d. Data aktivitas Kaizen yang mendapat final point akan langsung di submit melalui sistem aplikasi oleh Pimpinan HOS yang akhirnya masuk ke dalam database.

e. Kemudian Komite melakukan proses cetak laporan data aktivitas Kaizen yang telah diolah sehingga mendapatkan hasil Kaizen terbaik berdasarkan aktivitas yang memiliki nilai total point tertinggi.

f. Komite membuat laporan nominasi Kaizen terbaik kepada pimpinan HOS.

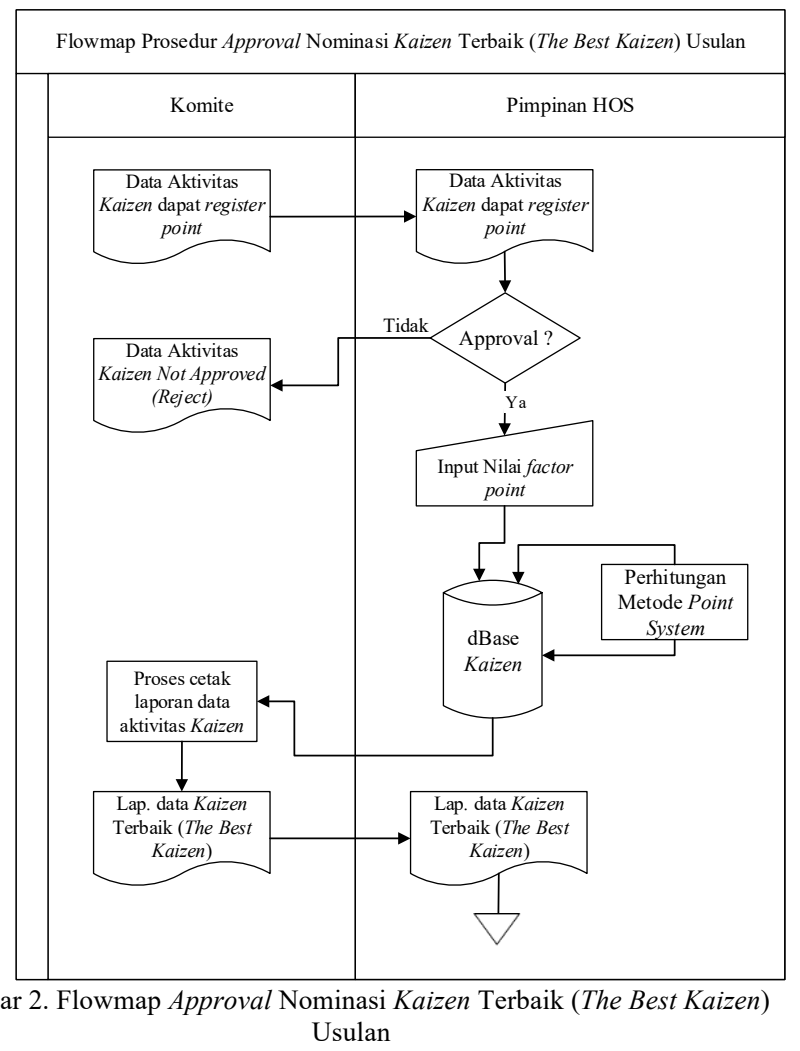

3. Diagram Konteks

Diagram konteks adalah diagram yang menggambarkan hubungan antara entitas eksternal dengan sistem. Dimana data yang diinputkan oleh bagian entitas eksternal akan diproses di dalam sistem dan akan menghasilkan laporan yang diinginkan oleh entitas eksternal tersebut.

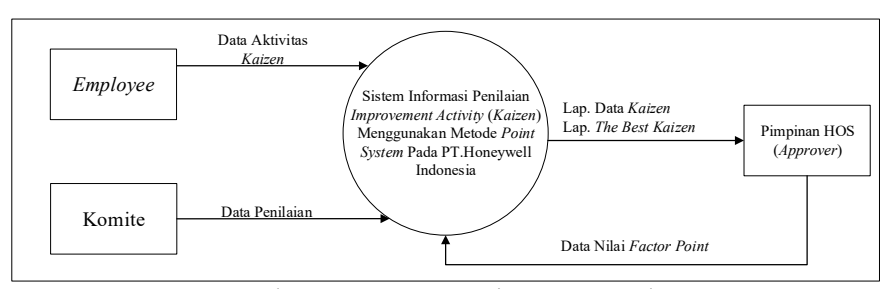

Gambar 3. Rancangan Diagram Konteks

\section{Data Flow Diagram (DFD) Level 0}

Diagram arus data mempunyai level atau tingkatan, level 0 merupakan diagram arus data yang mendasar dari sebuah proses, sedangkan level 1 dan seterusnya adalah merupakan pengambangan dari proses-proses yang ada pada level 0 yang bertujuan untuk lebih dimengerti dan dipahami. Untuk lebih jelas dapat dilihat pada gambar dibawah ini : 


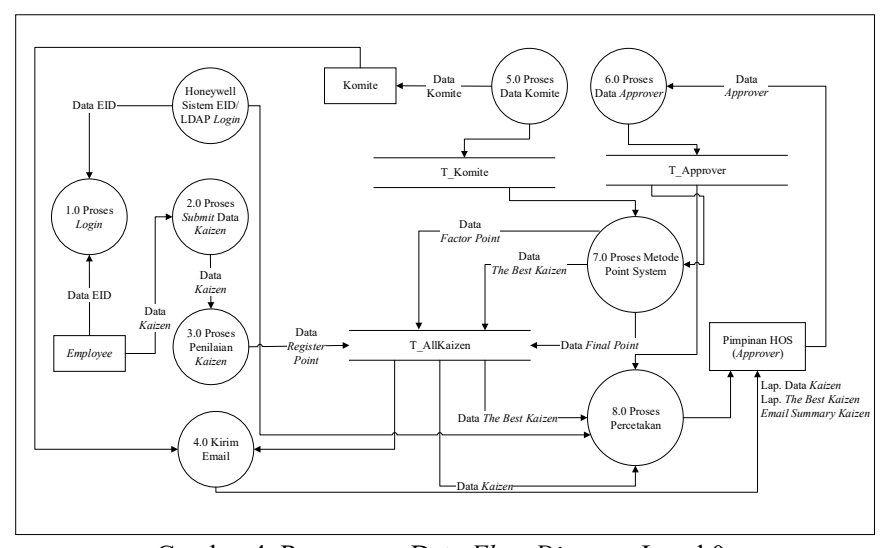

Gambar 4. Rancangan Data Flow Diagram Level 0

Proses nominasi Final Point dengan cara menggunakan Metode Point System, metode yang diintegrasikan dalam perancangan sistem usulan pada proses improvement activity (Kaizen) di departemen Honeywell Operating System.

Adapun tahap proses metode point system dalam rancangan aplikasi yaitu sebagai berikut :

\section{Menentukan Tingkat Kompleksitas Pekerjaan dan definisi setiap faktor.}

Adalah dimana metode penentuan yang dilakukan dengan cara memutuskan apakah kegiatan tersebut memiliki tingkat kerimutan atau tidak.

TABEL I

TABEL TINGKAT KOMPLEKSITAS PEKERJAAN

\begin{tabular}{|c|l|l|}
\hline \multicolumn{3}{|c|}{ Tingkat Kompleksitas Pekerjaan } \\
\hline $\begin{array}{c}\text { Tingkat } \\
\text { Kompleksitas }\end{array}$ & $\begin{array}{c}\text { Nama } \\
\text { Aktivitas }\end{array}$ & \multicolumn{1}{c|}{ Definisi Aktivitas } \\
\hline 1 & Just Do It & $\begin{array}{l}\text { Suatu improvement activity } \\
\text { dimana tingkat aktivitas } \\
\text { perubahan yang telah } \\
\text { dilakukan termasuk kategori } \\
\text { cukup sederhana (simple) } \\
\text { baik dalam hal waktu dan } \\
\text { usaha pengerjaan yang } \\
\text { dilakukan secara individu } \\
\text { maupun tim kelompok. }\end{array}$ \\
\hline \multirow{5}{*}{2} & Kaizen & $\begin{array}{l}\text { Suatu improvement activity } \\
\text { dimana tingkat aktivitas } \\
\text { perubahan yang telah } \\
\text { dilakukan termasuk kategori } \\
\text { rumit baik dalam hal waktu } \\
\text { dan usaha pengerjaan yang } \\
\text { dilakukan secara individu } \\
\text { maupun tim kelompok. }\end{array}$ \\
& &
\end{tabular}

2. Menentukan secara rinci faktor-faktor yang dapat dikompensasi (Compensable Factors).

Adalah dimana metode penentuan poin awal (register point) yang dilakukan dengan cara memutuskan apakah kegiatan tersebut memiliki syarat maksimal atau tidak yang nantinya akan mempengaruhi pemberian kompensasi nilai bobot (weight) akhir. Nilai register point didapatkan berdasarkan tingkat kompleksitas dari masing-masing tipe complexity.

TABEL II

TABEL REGISTER POINT BERDASARKAN TIPE COMPLEXITY

\begin{tabular}{|c|c|l|}
\hline $\begin{array}{c}\text { Tipe } \\
\text { Complexity }\end{array}$ & Point & \multicolumn{1}{|c|}{ Deskripsi } \\
\hline Simple & 1 & $\begin{array}{l}\text { Kaizen tanpa bukti pekerjaan } \\
\text { dengan gambar. }\end{array}$ \\
\hline Medium & 3 & $\begin{array}{l}\text { Kaizen dengan bukti } \\
\text { pekerjaan hanya 1 gambar. }\end{array}$ \\
\hline Complex & 5 & $\begin{array}{l}\text { Kaizen dengan bukti } \\
\text { pekerjaan lengkap dengan } \\
\text { gambar perubahan sebelum } \\
\text { dan sesudah. }\end{array}$ \\
\hline
\end{tabular}

\section{Membuat Definisi Faktor Kriteria yang di-Pilih.}

Adalah dimana metode penentuan kriteria yang dilakukan dengan cara membuat definisi dari setiap faktor dimana harus dibuat dengan bahasa yang sederhana dan mudah dipahami sehingga meminimalisasi kesalahpahaman dari para anggota tim. Definisi yang sudah dibuat dan disetujui menjadi acuan bagi pimpinan HOS dalam penentuan nilai Kaizen.

TABEL III

TABEL DEFINISI FAKTOR KRITERIA

\begin{tabular}{|c|c|c|c|c|c|}
\hline $\begin{array}{l}\text { Kriterial } \\
\text { Faktor }\end{array}$ & Mencoba & Berusaha & Memuaskan & Ideal & Istimewa \\
\hline Safety & $\begin{array}{c}\text { Tidak ada } \\
\text { pengaruhnya ke } \\
\text { safety }\end{array}$ & $\begin{array}{c}\text { Ada peningkatan } \\
\text { kebersihan, } 5 \mathrm{~S}\end{array}$ & $\begin{array}{c}\text { Ada peningkatan } \\
\text { kebersihan, } 5 S \text { dan } \\
\text { mengurang potensi } \\
\text { berbahaya }\end{array}$ & $\begin{array}{l}\text { Mencegah kerusakan } \\
\text { terhadap } \\
\text { produk/unit/peralatan } \\
\text { dan cedera karyawan }\end{array}$ & $\begin{array}{c}\text { Mencegah kecelakaan } \\
\text { fatal dan } \\
\text { membahayakan } \\
\text { terhadao keberadaan } \\
\text { perusahaan. }\end{array}$ \\
\hline Quality & $\begin{array}{c}\text { Tidak ada } \\
\text { pengaruhnya ke } \\
\text { quality }\end{array}$ & \begin{tabular}{|c|} 
Mengenalkan \\
perilaku yang \\
baik terhadap \\
peringatan \\
"workmanship" \\
workm
\end{tabular} & $\begin{array}{c}\text { Berdampak tidak } \\
\text { langsung terhadap } \\
\text { Yield dan PPM atau } \\
\text { persyaratan } \\
\text { customer/proses } \\
\text { berikutnya } \\
\end{array}$ & $\begin{array}{l}\text { Berdampak langsung } \\
\text { terhadap Yield dan } \\
\text { PPM atau persyaratan } \\
\text { customer/proses } \\
\text { berikutnya }\end{array}$ & \begin{tabular}{|c|} 
Secara nyata \\
berdampak terhadap \\
Yield dan PPM, atau \\
melebihi persyaratan \\
customer/proses \\
berikutnya \\
\end{tabular} \\
\hline \begin{tabular}{|c|} 
Deliveryl \\
Inventory
\end{tabular} & \begin{tabular}{|c|} 
Tidak ada \\
pengaruhnya ke \\
Delivery/ \\
Inventory
\end{tabular} & \begin{tabular}{|c|} 
Mengenalkan \\
perilaku yang \\
baik terhadap hal- \\
hal \\
mendesak/meny \\
ederhanakan \\
metode \\
\end{tabular} & $\begin{array}{l}\text { Pengurangan } \\
\text { penyelesaian kerja } 5 \% \\
\text { atau kurang }\end{array}$ & $\begin{array}{c}\text { Pengurangan } \\
\text { penyelesain pekerjaan } \\
\text { antara } 5 \%-10 \%\end{array}$ & $\begin{array}{c}\text { Peningkatan } \\
\text { pencapaian waktu } \\
\text { kerja atau lebih dari } \\
10 \% \text { penyelesaian } \\
\text { pekerjaan }\end{array}$ \\
\hline $\begin{array}{c}\text { Cost/Man } \\
\text { hour } \\
\text { reduction }\end{array}$ & \begin{tabular}{|c|} 
Tidak ada \\
pengaruhnya e \\
harga/jam kerja
\end{tabular} & \begin{tabular}{|c|} 
Mengenalkan \\
perilaku hemat \\
atau peringatan \\
terbadap \\
pemakaian \\
berlebih \\
\end{tabular} & $\begin{array}{c}\text { Penghematan } \\
\text { sebesar kurang dari } \\
\text { SGD50, atau } \\
\text { mengurangi waktu } \\
\text { kerja } 5 \text { to } 20 \text { mins }\end{array}$ & $\begin{array}{l}\text { Penghematan antara } \\
\text { SGD50-100, atau } \\
\text { mengurangi waktu } \\
\text { kerja } 20 \text { to } 30 \text { mins }\end{array}$ & $\begin{array}{c}\text { Penghematan lebih } \\
\text { dari SGD 100, atau } \\
\text { mengurangi waktu } \\
\text { kerja } 30 \text { mins atau } \\
\text { lebih } \\
\end{array}$ \\
\hline \begin{tabular}{|l} 
Innovation \\
/Creativity
\end{tabular} \mid & NA & \begin{tabular}{c|}
$\begin{array}{c}\text { Peningkatan } \\
\text { pengetahuan } \\
\text { kerja diarea kerja } \\
\text { masing2 }\end{array}$ \\
\end{tabular} & $\begin{array}{c}\text { Peningkatan disiplin } \\
\text { kerja dilingkungan } \\
\text { departemen/line } \\
\text { masing2 }\end{array}$ & $\begin{array}{c}\text { Peningkatan } \\
\text { semangat kerja. } \\
\text { Berlaku untuk } \\
\text { beberapa deptline }\end{array}$ & $\begin{array}{c}\text { Peningkatan kerja } \\
\text { produktif. Berlaku } \\
\text { disemua deptline } \\
\text { sebagai contoh terbaik }\end{array}$ \\
\hline
\end{tabular}

4. Menentukan level atau tingkat faktor-faktor yang dikompensasi yang didasarkan pada pertimbangan setiap faktor yang dikompensasi berbeda di antara pekerjaan.

Adalah metode level yang dilakukan dengan cara menentukan level sebuah aktivitas dari faktor yang memenuhi kriteria penilaian Kaizen atau tidak. 
TABEL IV

TABEL KRITERIA/FAKTOR POINT PENILAIAN KAIZEN

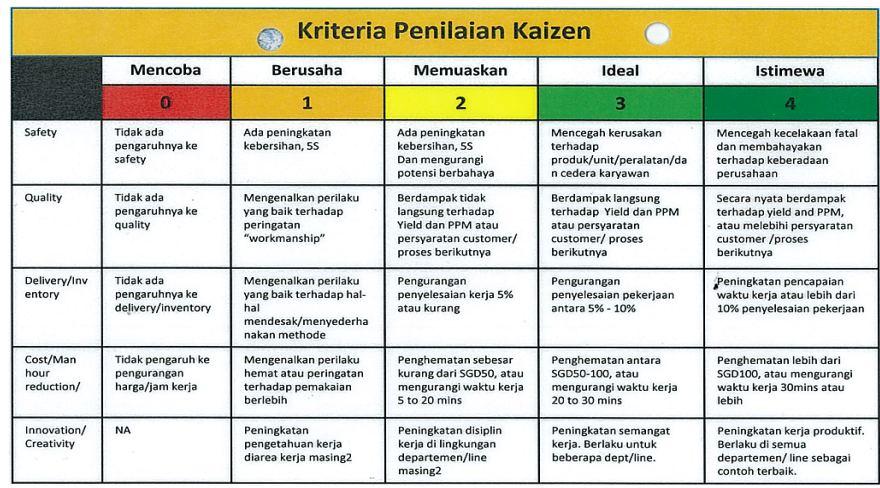

Tabel 3 dan 4 merupakan skala penilaian yang telah ditentukan oleh HOS Steering Comite, skala tersebut berdasarkan tingkatan penilaian yang dimulai dari sekedar mencoba hingga tipe istimewa dimana akan menyesuaikan jumlah poin yang akan diperoleh oleh karyawan. Kriteria proses penilaian ini telah ditentukan oleh HOS Komite dengan merujuk pada dokumen spesifikasi Honeywell Operating System (HOS) yakni Kaizen Self-Assessment yang terdapat pada intranet Aerospace Performance Dashboard. ${ }^{1}$

5. Menentukan bobot point untuk setiap faktor atau yang biasanya disebut dengan Work Grade atau Work Class. Dalam setiap Grade, maka kinerja akan mempunyai point (factor point) yaitu berupa angka yang akan dipakai menentukan tingkat improvement activity. Adalah metode point yang dilakukan dengan cara memeriksa dari suatu kegiatan improvement sudah masuk ke dalam kategori faktor-faktor yang telah ditentukan.

TABEL V

TABEL BOBOT POINT BERDASARKAN TIPE COMPLEXITY

\begin{tabular}{|c|c|c|c|}
\hline Item & $\begin{array}{c}\text { Weight } \\
\text { (Bobot) }\end{array}$ & $\begin{array}{c}\text { Factor } \\
\text { Point (0-4) }\end{array}$ & Grade Point \\
\hline Safety & 5 & $?$ & $?$ \\
\hline Quality & 5 & $?$ & $?$ \\
\hline $\begin{array}{c}\text { Delivery/Invent } \\
\text { ory }\end{array}$ & 5 & $?$ & $?$ \\
\hline $\begin{array}{c}\text { Cost/Man-hour } \\
\text { reduction }\end{array}$ & 5 & $?$ & $?$ \\
\hline $\begin{array}{c}\text { Innovation/Cre } \\
\text { ativity }\end{array}$ & 5 & $?$ & $?$ \\
\hline \multicolumn{4}{c}{ Total Point } \\
\hline
\end{tabular}

Adapun proses perhitungan total nilai point adalah didapatkan dari menghitung berapa banyak jumlah total item (disini sudah ditentukan ada 5 item) dimana tingkatan point faktor kriteria yaitu 0 sampai 4 dikalikan dengan bobot masing- masing item. Dimana factor point ditentukan oleh Pimpinan HOS sesuai tingkatan kriteria penilaian Kaizen dari 0-4. Kemudian setiap factor point akan dikalikan dengan bobot item untuk mendapatkan grade point.Proses penilaian totol point akan menentukan siapa karyawan yang mendapatkan nilai total point tertinggi yang akan menjadi the best Kaizen.

TABEL VI

TABEL MAXIMUM TOTAL POINT

\begin{tabular}{|c|c|c|c|}
\hline Item & $\begin{array}{c}\text { Weight } \\
\text { (Bobot) }\end{array}$ & $\begin{array}{c}\text { Factor } \\
\text { Point (0-4) }\end{array}$ & Grade Point \\
\hline Safety & 5 & 4 & 20 \\
\hline Quality & 5 & 4 & 20 \\
\hline $\begin{array}{c}\text { Delivery/Invent } \\
\text { ory }\end{array}$ & 5 & 4 & 20 \\
\hline $\begin{array}{c}\text { Cost/Man-hour } \\
\text { reduction }\end{array}$ & 5 & 4 & 20 \\
\hline $\begin{array}{c}\text { Innovation/Cre } \\
\text { ativity }\end{array}$ & 5 & 4 & 20 \\
\hline \multicolumn{4}{|c}{ Total Point } \\
\hline
\end{tabular}

Berdasarkan formula dibawah maka total maximum point adalah 100 .

\section{KESIMPULAN}

Setelah merancang dan membuat Aplikasi Penilaian Improvement Activity (Kaizen) Menggunakan Metode Point System Pada PT.Honeywell Indonesia yang dibuat, Penulis menyimpulkan bahwa :

1. Proses sistem informasi Penilaian Kaizen ini yang dimulai dari proses submission kaizen dan pengolahan data kaizen dapat dilakukan hanya dengan input data detail suatu kaizen (kegiatan improvement) dan pengolahan data serta pembuatan laporan dalam satu proses komputerisasi yakni pada satu proses aplikasi yang terintegrasi secara otomatis.

2. Dengan adanya sistem informasi penilaian Kaizen berbasis aplikasi ini mempermudah team member yakni manajer dan komite tanpa harus mencatat data secara manual lagi ke dalam Opportunity Sheet dan tidak perlu lagi menyusun ulang ke dalam Microsoft Excel.

3. Sistem dilengkapi feature (alat bantu) yakni auto-email yang membantu tim member dapat sebuah notifikasi kaizen yang instan langsung masuk ke inbox email dan akhirnya mempercepat proses penilaian suatu Kaizen.

Berikut saran-saran untuk penelitian lanjutan jika diperlukan :

1. Implementasi SharePoint Server buatan Microsoft yang berfungsi mengintegrasikan aplikasi Microsoft Visual Bacic berbasis aplikasi desktop yang dapat dikonversikan menjadi berbasis web based dan juga berbasis smartphone. 
Disini penulis memberi saran ke perusahaan untuk diberi kesempatan merancang aplikasi ini sehingga dapat diakses di browser dan smartphone.

2. Penggunaan aplikasi ini dengan profesional sehingga setiap aktivitas Kaizen yang di-submit merupakan data yang valid dan bukan asal-asalan karena secara otomatis email akan langsung meluncur ke manajer karyawan tersebut.

3. Dari segi penggunaan untuk mengoperasikan aplikasi ini diharapkan user adalah karyawan sudah memiliki pengetahuan yang cukup tentang komputer hingga petunjuk penggunaan (manual guide book) juga akan segera diluncurkan dalam waktu dekat.

\section{REFERENSI}

[1] Anonim. Panduan Penulisan Laporan Kerja Praktek dan Tugas Akhir, STTI, 2014, Tanjungpinang.

[2] Adi Nugroho, Analisa dan Perancangan Sistem Informasi dengan Metodologi Berorientasi Objek, [Andi, 2014, Yogyakarta].

[3] Rogers S.Pressman,Ph.D,Rekayasa Perengkat Lunak : ANDI, Yogyakarta, 2002.

[4] Edhy Sutanta, Sistem Basis Data:Graha Ilmu,Yogyakarta,2004.

[5] Handayani, 2005. Kaizen Culture, Education and Training, New York: Irwing .

[6] Hirano, 2005, Productivity by Kaizen, Jakarta: Pustaka Utama.

[7] Masaaki Imai, 2005. Budaya Kaizen, Jakarta: Pustaka Utama.
[8] Abdullah, Ma'ruf. 2014. Manajemen dan Evaluasi Kinerja Karyawan. Yogyakarta: Aswaja Pressindo.

[9] Hosra Afrizoni. 2015. "Kompensasi dan Kompetensi dalam Peningkatan Kinerja Pegawai". Tesis di Universitas Widyatama Bandung.

[10] Dwi Kurniawan, Penentuan Gaji Pokok Manajer Menengah dengan Metode Point System, Institut Teknologi Nasional (2012, Bandung).

[11] Definisi Bahasa Pemograman Acess : Hengky Alexander Mungkulo, 212 tip \& trik Acces 2010, [PT Elex Media kupotindo, 2015, Yogyakarta].

[12] Definisi Bahasa Pemograman Visual Basic : Edy Winarno ST,M,Eng, Ali Zaki dan Smit Dev Community, Belajar pemograman VB 6 dalam sekejap, [PT Elex Media kupotindo, 2015, Yogyakarta].

[13] Dokumen spesifikasi HOS Kaizen Self-Assessment [Online] tersedia di:https://in.honeywell.com/BusinessFunction/sixsigma/Tools/SixSigm aToolsStyleLibrary/Kaizen.html\#tabLearning/ [diunduh: 3 Desember 2017, 20.10 WIB].

[14] Jurnal encepsupriatna.files/2009/02/flowmap.pdf [Online] tersedia di:http://www.ijns.html [diunduh: 15 Agustus 2017, 20.00 WIB].

[15] Jurnal pengertian-dan-contoh-data-flow-diagram [Online] tersedia di:http://www.ijns.html [diunduh: 30 Agustus 2017, 17.00 WIB].

[16] Pengertian Konsep Dasar Sistem Basis Data, [Online] tersedia di:http://www.fairuzelsaid.com/konsep-dasar-sistem-basis-data.pdf [diunduh: 09 Agustus 2017, 21.00 WIB].

[17] Pengertian Entity Relationship Diagram, [Online] tersedia di:http://www.materibelajar.com/2016/04//pengertian-erd-entityrelationship.pdf [diunduh: 09 Agustus 2017, 18.00 WIB].

[18] Pengertian Dan Contoh Relasi One To One, One To Many [Online] tersedia di:http://www.materibelajar.com/2016/04//contoh-relasi-oneto-one-one-to-many.pdf [diunduh: 07 Agustus 2017, $08.00 \mathrm{WIB}$ ]. 